\title{
Crisis Nationalism: To What Degree Is National Partiality Justifiable during a Global Pandemic?
}

\author{
Eilidh Beaton $^{1} \cdot$ Mike Gadomski $^{2}$ (D) $\cdot$ Dylan Manson $^{2} \cdot$ Kok-Chor Tan $^{2}$
}

Accepted: 15 January 2021 / Published online: 14 February 2021

(C) The Author(s), under exclusive licence to Springer Nature B.V. part of Springer Nature 2021

\begin{abstract}
Are countries especially entitled, if not obliged, to prioritize the interests or well-being of their own citizens during a global crisis, such as a global pandemic? We call this partiality for compatriots in times of crisis "crisis nationalism". Vaccine nationalism is one vivid example of crisis nationalism during the COVID-19 pandemic; so is the case of the US government's purchasing a 3-month supply of the global stock of the antiviral Remdesivir for domestic use. Is crisis nationalism justifiable at all, and, if it is, what are its limits? We examine some plausible arguments for national partiality, and conclude that these arguments support crisis nationalism only within strict limits. The different arguments for partiality, as we will note, arrive at these limits for different reasons. But more generally, so we argue, any defensible crisis nationalism must not entail the violation of human rights or the worsening of people's deprivation. Moreover, we propose that good faith crisis nationalism ought to be sensitive to the potential moral costs of national partiality during a global crisis and must take extra care to control or offset these costs. Thus, crisis nationalism in the form of vaccine nationalism or the hoarding of global supplies of therapeutics during a global pandemic exceeds the bounds of acceptable partiality.
\end{abstract}

Keywords National partiality · Special obligations · Crisis nationalism · Vaccine nationalism · COVID-19 pandemic $\cdot$ Global justice

Mike Gadomski

mgadomsk@sas.upenn.edu

Eilidh Beaton

eilidh.beaton@kcl.ac.uk

Dylan Manson

mansond@sas.upenn.edu

Kok-Chor Tan

kctan@sas.upenn.edu

Extended author information available on the last page of the article 


\section{Introduction}

Moral partiality, that is, the permission or even obligation to favor some over others, is a wellcovered topic in philosophy. In the global justice literature, a central problem of partiality is that of national partiality. To what extent may governments of affluent countries favor the interests and needs of their own citizens and residents over the interests and needs of nonmembers? How is national partiality to be balanced against countries' obligations of global justice? What justifies (if at all) national partiality and what are its limits?

Much of the discussion on the basis and limits of national partiality presumes the circumstances of what we may call "ordinary" justice. Here the question is the distribution of goods that are relatively scarce (there would be no need to worry about global distributive fairness otherwise) but not abjectly scarce. ${ }^{1}$ In the ordinary case, it may be easier to establish the boundaries of acceptable national partiality, especially in the case of more affluent countries, where partiality typically involves favoring the less urgent interests of one's own over the more urgent ones of strangers. On this view, a limitation to national partiality is that the impartial duty to protect more urgent needs or interests of individuals in general outweighs any special favoring of the comparatively less urgent needs or interests of conationals.

But do the considerations for or against national partiality change in a crisis situation, where the problem is the allocation of abjectly scarce goods that are necessary for meeting equally urgent needs or interests? Is the case for national partiality more compelling during a crisis? The COVID-19 pandemic presents a scenario of this kind. ${ }^{2}$ Before vaccines became available, the American government made deals with pharmaceutical companies to purchase the global supply of Remdesivir (an antiviral against COVID-19), thereby depriving other countries of access to a potentially life-saving drug. Earlier in the global outbreak, the United States also tried to hoard and even hijack scarce medical supplies and equipment (ventilators, PPE) in the name of saving American lives. ${ }^{3}$ Now, at the time of writing, vaccines are just beginning to become available, and rich countries have already purchased far more than their fair share. According to the People's Vaccine Alliance, although rich countries make up just $14 \%$ of the world's population, they have secured $53 \%$ of the most promising vaccines - "enough doses to vaccinate everyone nearly three times over" - while nine out of ten people in 70 low income countries are unlikely to be vaccinated at all next year (Boseley 2020). ${ }^{4}$ Director of the Africa Centers for Disease Control and Prevention, John Nkengasong, has warned that Africa might not see vaccines at all until after the second quarter of 2021, calling this a "moral issue" and urging the UN to summon a special session to discuss the ethical and fair distribution of vaccines (Al Jazeera 2020).

\footnotetext{
${ }^{1}$ In this sense, we are understanding the distinction between "ordinary" circumstances and "crisis" circumstances in a particular way, relating to scarcity of some particular goods of interest. This is in the spirit of the "circumstances of justice" described by John Rawls (1999, pp. 109-12), following David Hume. We do not mean to deny that for a great number of people, everyday life (whether or not during a crisis in this specific sense) is marked by conditions of crisis in the ordinary language sense.

${ }^{2}$ Our basic analysis can be generalized to other cases of global health emergency and health challenges due to global crises like climate change. We thank a reader for suggesting that we note this wider application of our paper.

${ }^{3}$ See, for example, Donald Trump's attempt to ban exports of M N-95 masks to Canada during the COVID-19 pandemic.

${ }^{4}$ The People's Vaccine Alliance includes Amnesty International, Frontline AIDS, Global Justice Now and Oxfam. The quotation comes from Dr. Mohga Kamal Yanni from the Alliance.
} 
At present, vaccines are still abjectly scarce - we have yet to produce enough to vaccinate enough of the world's population to achieve global herd immunity. While this continues to be the case, are governments permitted, or even obliged, to stockpile as many doses of available vaccines as they can to protect the health of their own citizens and achieve sufficient immunity in order to restart their economies? Is this "vaccine nationalism" justifiable (Bollyky and Bown 2020)? Is partiality during crisis, or "crisis nationalism" as we will call this, more obviously justifiable than partiality in "normal" times? After all, when basic rights or interests are at stake on both sides, shouldn't shared nationality or citizenship make a moral difference?

We will argue that the case for crisis nationalism is more complicated than it might seem. The most plausible defenses of national partiality presume that there are impartial global duties from which special obligations derive or that put constraints on the proper exercise of partiality. If this is an acceptable starting point for justifiable partiality, then prioritizing conationals, even during a crisis, is morally questionable: (i) if the exercise of partiality denies other countries equivalent opportunities to acquire life preserving goods, or (ii) if it exacerbates existing global injustice, or (iii) if its exercise is made possible because of existing unfair advantages. When background global injustice has enabled some countries to respond while others are unable due to extreme deprivation, or where the exercise of partiality by affluent nations will have the effect of further depriving other nations of important goods or aggravate existing global injustices, crisis nationalism (on the part of rich nations) is harder to justify.

With these conditions of permissible partiality in mind, we will examine three approaches to justifying national partiality. These approaches, we believe, cover the main defenses of national partiality in the contemporary literature. The first approach defends partiality as an efficient division of labor for the purpose of achieving the best global outcome. That is, partiality on this approach is justified instrumentally. We will call this (i) the instrumental approach. The second approach claims that there is something special about the institutional character of the state such that it obligates the state to show special concern for members. We will call this the (ii) institutional approach to partiality. The third approach appeals to the ideal of shared nationality itself as the source of special concern among conationals. We will call this (iii) the "relational" approach. We will suggest that these approaches do not support unlimited crisis nationalism. Even when national partiality is motivated by the need to protect a basic right or interest of a compatriot, there are complicating moral factors that have to be taken into consideration and which put limits on the degree of partiality that is permitted.

Before we begin, a comment on terminology. By national partiality we mean (as it is commonly understood) the favoring of the members (i.e., citizens and permanent residents) of a state by its government. Some defenses of national partiality (as noted above) appeal to the special character of states; others, however, explicitly appeal to some ideal of a shared national identity or culture. But we take these to be different ways of defending what is normally and broadly called national partiality. Thus our examination of arguments for national partiality is not limited to arguments that explicitly invoke the concept of a national culture. Accordingly, we will use "compatriots" and "conationals" interchangeably, and "national" partiality can as well be replaced by "compatriot" partiality (and vaccine "nationalism" by vaccine "patriotism"). ${ }^{5}$

\footnotetext{
${ }_{5}^{5}$ One may worry that even though "compatriot" and "conational" are interchangeable, "nationalism" and "patriotism" are not. Maurizio Viroli (1995), for instance, makes the case that while nationalism is inward looking and objectionably hierarchical, patriotism is outward looking and recognizes the pursuit of liberty for all. We take no stand on these issues and only mean to use the terms in reference to national partiality. We thank an anonymous reviewer for bringing this issue to our attention.
} 
It is also worth noting that nationalism or patriotism rears its other heads in times of crisis. The COVID-19 pandemic, for instance, has resulted in increased xenophobia, racism, the closing of borders and a growing skepticism of globalization. Yet nationalism in a crisis is not necessarily repugnant (e.g., Bieber 2020). The strong sense of national solidarity in New Zealand, that both contributed to and is further reinforced by its successful suppression of COVID-19, does not seem misplaced or objectionable. Our discussion, in any case, bypasses these other dimensions of nationalism and is focused exclusively on the problem of partiality: to what extent are governments permitted to favor the interests and well-being of their own during a crisis with respect to the distribution of scarce goods?

Finally, we note there might well be good reasons, grounded in a concern for compatriots, not to exercise excessive partiality. For example, an extreme form of vaccine nationalism (that denies other countries any chance of immunizing their populations from COVID-19) can be counter-productive in that unless a country is prepared to hermetically seal itself off from the rest of the world, it cannot effectively protect its own citizens if the pandemic rages on elsewhere. Arguments against excessive partiality from national self-interest ultimately turn on the empirics of the situation, a country's conception of its own interests and what trade-offs it is prepared to make in light of these perceived interests, and so on. But they are not without merit, especially in the case of a global pandemic such as COVID-19 (where no one country can be safe unless others are). Be that as it may, whether or not countries indeed have selfinterested reasons to moderate their exercise of crisis nationalism, our aim in this paper is to make the case that there are also principled reasons for limiting or conditioning the exercise of national partiality.

\section{The Instrumental Approach}

According to the instrumental approach, nationally partial policies are justified because they serve universal and impartial moral goals (Goodin 1988; Nussbaum 1996; Arneson 2016). According to this view, although special relationships with conationals are not sources of moral duties in themselves, we should recognize special duties to compatriots for instrumental reasons, because doing so is an efficient and effective way to distribute general moral duties. In essence, acting partially can be a useful vehicle for fulfilling impartial moral requirements.

According to accounts of this sort, it is permissible, even desirable, for state officials to concern themselves with only the interests of their own members when they engage in policymaking. But this is permissible only because a global system which "divides the labor" for promoting individuals' legitimate interests across states is more efficient than a system in which there is no entity assigned with the responsibility for fulfilling any particular individual's interests. Just as patients receive better care when each doctor is only responsible for a subset of patients in their hospital, such that each patient is uniquely assigned to one particular doctor, so too will the interests of individuals across the world be better promoted when there is a particular entity - their state - assigned with the responsibility of promoting their interests (Goodin 1988, p. 681).

Even in non-crisis situations, the instrumental approach places relatively stringent limits on the scope of permissible partiality to co-nationals. Special duties are highly susceptible to being overridden because their moral force is derived entirely from general duties. For instance, under such views, safe states have strong (albeit imperfect) duties to assist refugees. This is because refugees are individuals who have not been assigned an advocate within the 
international state system, and the state system derives its justification from the assumption that every individual is assigned to an advocate who will effectively promote their interests (Goodin 1988). Moreover, because special responsibilities are mere administrative devices for fulfilling general duties, the instrumental approach also asserts that each state must possess sufficient capacity and resources to effectively discharge its responsibilities to its citizens. When states lack such capacity, other states have obligations to assist them. Otherwise, the entire administrative system will be in need of reconstitution (Goodin 1988).

Similar considerations would also apply in circumstances of crisis. The instrumental approach essentially affirms the priority of principles of global justice, since - as its name suggests - special duties to conationals are only instrumentally justified in terms of general principles. As such, if patriotic concerns came into conflict with principles of global justice in a crisis situation, the view demands that state agents act only on the latter (Tan 2003).

With these considerations in mind, it is ultimately an empirical question whether the instrumental approach would endorse policies of national partiality in any particular crisis context. It is true that this approach might permit particular countries to implement nationally partial policies which genuinely serve to promote the impartial moral good during times of crisis. To take the example of the COVID-19 pandemic, for instance, the instrumental approach might permit countries with large populations, or countries with large elderly populations, or low-income countries with less robust healthcare infrastructure to implement vaccine-hoarding policies if there was good reason to think that this could be part of a global strategy which efficiently served to reduce the total number of individuals facing direct or indirect threats to their basic needs as a result of COVID-19.

However, it must be emphasized that the instrumental approach would only endorse nationally partial policies if they aligned with general principles of justice. In deeply unequal worlds like our own, such policies would typically only be acceptable if they embodied acts of solidarity among the disadvantaged. But questions about the permissibility of partialist practices which express solidarity among the disadvantaged are quite different from questions about the acceptability of partial policies which stand in tension with general global duties. Because partiality is justified only instrumentally on this account, it would deny that considerations of partiality can mute global obligations, even in times of crisis. ${ }^{6}$

Moreover, again, it is an empirical question whether the instrumental approach would permit nationalist policies, and - at least in the current context - evidence suggests that nationalistic policies are not efficient means to fulfilling the basic needs of all people. In our increasingly globalized and interdependent world, cooperation, as opposed to national insularity, is typically the most effective response in times of crisis. For instance, experts generally agree that the most effective way to end the COVID-19 pandemic is to distribute vaccines according to need, not according to which country can pay the highest price (see, e.g., Yamey et al. 2020). But coordinated global cooperation, not a system predicated on the assumption of

\footnotetext{
6 This evaluation is in line with the UN Secretary-General's recent statement to the Nobel Peace Prize forum that: "The COVID-19 crisis has shown above all the urgent need for human solidarity [...] such solidarity is not only a moral imperative; it is in everyone's interests." (UN Secretary General, 2020). This statement suggests that partiality that is incompatible with cosmopolitan solidarity is unacceptable. For philosophical accounts of solidarity, see e.g. Iris Young (2011, pp. 120-121), "solidarity is a relationship among separate and dissimilar actors who decide to stand together, for one another [...] a relationship among many people who recognize and take up a shared responsibility in relation to the social institutions and practices they enact and support, to make them just". For a detailed account of solidarity in the particular context of global health, see West-Oram \& Buyx (2017).
} 
self-interested unilateralism, is the most effective method of ensuring that this sort of distribution occurs. ${ }^{7}$ Without such cooperation, we may end up in a situation in which lower-risk affluent nations hoard much more than their fair share of life-saving supplies, at the expense of at-risk individuals in other countries. The instrumental approach can quickly run afoul of one of the constraints of justifiable partiality that we noted in the introduction. Where partiality under crisis in practice fails to provide an effective division of labor for meeting global needs, its exercise straightforwardly denies others equivalent opportunities to protect themselves.

In sum, the instrumental approach provides a highly contingent justification for national partiality in times of crisis because it does not recognize special relationships with co-nationals as an independent source of moral obligation. As such, even in "ordinary" imperfect contexts, this approach predicts that it would be morally wrong for individuals and policymakers to prioritize the claims of compatriots against the more urgent claims of non-co-nationals (Goodin 1988). Since this approach is predicated on the idea that impartial and universal morality is the only source of moral duty, whether nationalistic partiality will be permitted by this account depends entirely on contingent facts of the particular situation - on whether partiality is, in fact, an efficient means of fulfilling impartial moral duties in this particular context. As outlined above, in our increasingly globalized world, there is good reason to think that this will rarely be the case.

\section{The Institutional Approach}

The second approach to partiality does not treat partial concern among conationals to be merely of instrumental value. Instead it argues that national partiality derives from the fact that conationals, qua citizens of a state, are fellow participants under a common political, social and economic institutional arrangement or scheme.

But what is so special about the institutional structure of the state that creates and justifies partiality among participants? One common view is that the state is fundamentally a coercive institution. Partial concern is necessitated to legitimize the coercive authority of the state. The other view is that the institution of the state is a cooperative one. Partial concern for one's fellow citizens is what reciprocity under fair cooperation requires (or at least permits). Do either of these views provide a justification for partiality during a global crisis? We will first outline each view and then evaluate them together, since our main criticisms target the common form of both arguments. ${ }^{8}$

\subsection{The Coercion View}

To locate the distinctiveness of the state, some commentators have argued the state is an ongoing and legal coercive scheme in a way that the global order as a whole is not. That is, the

\footnotetext{
${ }^{7}$ See West-Oram \& Buyx (2017) for a discussion on this point.

${ }^{8}$ Another reason to treat these views together here is that they are both influential interpretations of Rawls, specifically his views about why the so-called "basic structure" is of special importance to distributive justice. Coercion theorists like Blake (2001, p. 283), for example, claim that "the real purpose of the difference principle is to justify coercion to all those coerced” (see also Valentini 2011). Freeman (e.g., 2007a, pp. 101-102), on the other hand, argues that for Rawls, it is the fact that the basic structure is necessary for social cooperation that makes it so important (see also Sangiovanni 2008). Freeman notes that this would be true whether or not coercive force was necessary to maintain it. Though we have our inclinations, there is no need to take a stand here on what the "correct" interpretation of Rawls is. For further discussion, see Abizadeh (2007).
} 
state is an entity that is able to lawfully exercise force over its citizens and has the authority to determine their legal rights, entitlements and obligations. It is this fact of lawful coercion that generates egalitarian commitments among members of a nation-state; and because there isn't a lawful global coercive authority, there is no similar reason for caring about global equality (Blake 2001; R. Miller 1998; Nagel 2005). These views establish a kind of partiality in the sense that we owe certain duties to conationals (duties of egalitarian distributive justice) that we do not owe to non-conationals. ${ }^{9}$

One important line of argument draws on the idea of individual autonomy, in that since lawful coercion is, in the first instance, autonomy-restricting, it must be justifiable to those being coerced if it is to be legitimate (Blake 2001). Such an arrangement would be justifiable, on this account, if significant special consideration were given to fellow members. One such special consideration is that of not allowing for arbitrary inequalities among members. That is, a coercive order is acceptable in spite of its restrictions on autonomy if it is tempered by some institutionalized distributive egalitarian commitments among all persons living under the arrangement. For example, the civil laws that society enforces, laws that determine contractual rights, ownerships, taxation and so on, are prima facie restrictions on persons' autonomy, and this system of coercion is legitimate only if can be acceptable to all, in particular to those who are most significantly relatively disadvantaged (ibid.). This presents a consideration in favor of mitigating the situation of the worst off under this arrangement via some egalitarian distributive arrangement.

The coercion argument is thus a two-step argument: it first makes a normative claim that special duties to conationals that are triggered under the condition of state coercion; and it makes a second, empirical claim that the global order is not a coercive order in the relevant sense.

\subsection{The Cooperation View}

The second account in defense of special duties to compatriots emphasizes the ideal of reciprocity under social cooperation. The state is a cooperative system that governs the economic life of participants in ways that the global domain does not. The state dictates the terms of ownership, of transfers, of contracts, makes laws regulating wages and income and work hours, and so on (Freeman 2007b, chap. 9). It also provides the basic economic infrastructure for economic activities and transactions to take place, such as law and order, roads, postal and communication services, methods of adjudicating disputes and enforcing contracts, the educating of a workforce, etc. Under the cooperative system of the state, individuals are more deeply entangled economically and thus more mutually obliged than they are in the global context (Sangiovanni 2007). In fact, the success of anyone within an economic system cannot be understood without attribution to the social and economic background conditions that the state creates and sustains, and which members of society contribute to and participate in. Participants in a shared economic system, so understood, thus stand in a special kind of reciprocal relationship. It is the ideal of reciprocity under the context of economic cooperation that motivates the special concern for conationals. It is this special quality of the state that distinguishes it from the global arena as a whole.

The social cooperation argument, like the coercion argument, is a two-step argument. It first makes the normative claim that social cooperation is what activates special obligations; then it

\footnotetext{
${ }^{9}$ For a critical discussion of the merits of these arguments (and others) as anti-global egalitarian arguments, see Barry and Valentini (2009).
} 
argues that while the state constitutes a cooperative arrangement of the sort that gives rise to egalitarian duties among conationals, the global arena does not. Persons don't stand in the same kind of cooperative relationship with each other internationally.

\subsection{Evaluation}

Both the coercion and cooperation views share this common form, so we can evaluate them together. Let's look at the last (empirical) premises of these arguments first. Consider the coercion view. Some commentators have argued in response to the coercion view that the global order is a suitably coercive for the purpose of generating egalitarian obligations. Trade conventions, international norms and laws restrict individual and state conduct globally, and such restrictions are often backed by sanctions of varying kinds, such as trade retaliation, withdrawal of cooperation, imposition of embargos, and even military intervention in cases of extreme transgressions. It is often pointed out as well that what appears to be an instance of domestic law making, such as imposing restrictive immigration policies, has coercive implications for individuals in the world at large (Abizadeh 2008). Borders keep people out and are protected by armed guards (Carens 1987).

The same goes for the cooperation view. The cooperation argument points to economic institutional facts and laws, such as property rights, contract laws, laws regulating transfers and transactions and the like, to show why egalitarianism applies within the state. Are there not similar economic institutions within the global arena? Could one argue that international laws and norms regulating territorial rights, ownership of natural resources, and the international intellectual property rights regime are examples of global institutions and laws that establish and define ownership? Is the economic success of one country really so detached from and independent of the background international economic structure? Again, the point is not merely about whether or not the global political order is in fact a scheme of social cooperation - clearly, the state is in many ways not this, and yet it is still useful, according to these theorists, to conceptualize it as such. The question is: given the facts, why not conceptualize the global arena in this way as well?

But even if the empirical premises of the coercion and cooperative views hold, their normative premises do not justify national partiality during a global crisis. What the normative premises seek to establish is that there are special duties that are created by the fact of coercion or cooperation. But this is consistent with the belief that, nonetheless, global duties set limits on the range of special national duties that can be generated by coercion or cooperation (see e.g. Scheffler 1994). For example, you and I cannot unilaterally decide to form a coercive or cooperative scheme between us, and by appeal to this special arrangement and the special duties we now owe to each other, release ourselves from our outstanding general (impartial) duties to others. In other words, whatever is true about the duties of justice generated by coercive or cooperative institutional arrangements, it is implausible that they are the only duties of justice that we have. This means that the institutional schemes, and whatever duties flow from them, rather than being simply self-justifying, must be reconciled in some way with our general duties.

Indeed, the special national duties that the main coercion and cooperation arguments in the contemporary literature seek to defend are egalitarian distributive duties, or duties directed at limiting inequalities between persons, rather than simply at ensuring that no person falls below a particular threshold. That is, their proponents are mainly making the anti-global egalitarian thesis, by arguing that egalitarian duties are activated only within the state (because of coercion or cooperation) but not globally (because it is not coercion or cooperative in the relevant sense). But they in fact acknowledge that there are universal impartial duties to respect basic human rights, to address basic needs of people, and so on. These impartial global duties are 
independent of facts of cooperation or coercion and have primacy over special nationalist duties. That is, none of these anti-global egalitarians will say that a state may violate its basic responsibilities to other people in the name of furthering egalitarian justice at home. So even if the cooperation and coercion views succeed in defending special duties to compatriots, they do not defend the kind of absolute priority that is at issue.

But suppose we are faced with a case of conflict between the basic rights of members versus the rights of others. Is membership in the state not morally relevant here? Could the coercion or cooperation view not recommend favoring one's own when there is this stark trade-off to be made? In light of this challenge, we will recall a comment made above, that schemes of cooperation or coercion are not self-justifying. How these schemes operate, what goals they may collectively pursue and what they are entitled to for purposes of their internal distribution, are constrained by preexisting impartial duties that people owe to each other. We may not form a cooperative scheme that expropriates more than our fair share of goods against other schemes or non-participants; we cannot form special arrangements to pursue goals that are ruled out from some impartial moral perspective from the outset. While members of social schemes of cooperation or coercion have special duties to fellow participants, justice between social schemes is important and sets limits on what goods are available for internal distribution.

So, to properly understand whether it is justifiable for states to privilege their own members' basic rights over those of others during a global crisis, we cannot avoid the issues of background global injustice raised in the introduction. Are some states (qua schemes of cooperation or coercion) unfairly advantaged over others and so better able to lay claims on the scarce right-protecting goods? Are some schemes themselves unjust in the way they include and exclude people from participating in their arrangements? Very plausibly, the answer to these questions is 'yes.' And if this is correct, then unjustly advantaged states cannot rightly cite their unique coercive or cooperative institutional scheme as grounds for protecting their own members' basic rights at the expense of those of non-members. Doing so against the background of acknowledged unfair advantage constitutes a violation of an impartial duty — namely, the duty of justice to work towards correcting existing injustice.

We do not claim that national partiality is never justifiable under crisis. What we are arguing is that whether partiality under crisis is defensible or not will depend on facts of background justice - how different schemes stand in relation to each other. Under the nonideal conditions of the real world, a world characterized by unjust socio-economic inequalities, etc., it is far from obvious that the institutional relationship between conationals is per se decisive in granting partiality. When existing global injustices have enabled some countries to exercise crisis nationalism, the case for partiality is morally suspect.

\section{The Relational Approach}

The above approaches attempt to justify partiality by reference to some universal impartial goal or principle. We turn now to arguments that partial duties are non-reductively relational in that they are intrinsic to some ideal of a relationship. ${ }^{10}$ For instance, on the relational approach,

\footnotetext{
${ }^{10}$ One may wonder whether some versions of the institutional approach are distinct from the relational approach. A national group may be non-instrumentally valuable, for instance, because it is cooperative. This shows the views have some overlap. They still remain distinct, however, since non-instrumentally valuable groups aren't necessarily cooperative (as members of adversarial families can attest), and cooperative groups aren't necessarily non-instrumentally valuable (since they may act under contract for a specific goal, for example). We thank an anonymous reviewer for pushing us to clarify this point.
} 
friends have special duties to each other not because this is an efficient way of realizing impartial goods, or because some impartial ideal of cooperation warrants it, but because it is definitive of what it means to be in an ideal friendship (Miller 1995, 2007; Moore, 2001, 2015; Scheffler 2001, 2018; Lazar, 2010, 2016; Banai and Kollar 2019). With respect to national partiality, relational theorists argue that special concern for conationals is intrinsic to the ideal of conationality. For relational theorists, it is intrinsic to the idea of belonging to a common national community that people see themselves to be specially and mutually indebted to their fellow members (e.g. Miller 2007; Scheffler 2018; Moore 2001). For instance, David Miller writes, "nations are communities whose members see themselves as having obligations of mutual aid that are more extensive than the aid they owe to human beings generally" (2007, p. 131 , italics added). It is just part of what it means to be in relationship of conationality that people "see themselves" to have this special concern for each other. We can call this nonreductive relationship-dependent argument for partiality the relational view.

It is worth noting quickly that relational accounts of national partiality are not uncontroversial. First, not all forms of national relations are non-reductively or intrinsically valuable. For instance, some kinds of national relations - those associated with what we might call illiberal nationalism that are based on exclusion and xenophobia, or condone domestic injustices, do not constitute communities of mutual aid. But even if the arguments for partiality are limited to liberal forms of nationalism, relational arguments face some difficulties. National relations seem qualitatively different from friendship or kinship in that they lack the personal intimacy and proximity that typifies the latter forms of relationships. So even if special concern for friends and family is nonreductively relational, it is less obvious that the same argument can be made for national partiality (Wellman 2001, McMahan 1997, Hurka 1997).

But even if we grant the plausibility of relational accounts of national partiality, they do not justify absolute priority or partiality without limits. Like the coercion and cooperation theorists discussed above, relational theorists generally accept moral limits to national partiality. Miller for instance notes national partiality is limited by respect for universal human rights (Miller 2007 chap. 7 esp. ff. 185, and chap. 9 esp. ff. 249). Samuel Scheffler takes it as a given that there are impartial moral duties. He makes the case for non-reductive partiality for the purpose of showing that there is a "problematic" tension within morality between impartial duties and special responsibilities that moral philosophy has to confront (e.g., Scheffler 2001; pp. 95-96).

Where the precise limits of acceptable partiality should fall is not something we need to address here. Different relational theorists will understand the limits differently. What is important is that, wherever they might draw the limits themselves, relational theorists accept respect for the basic human rights of others as an upper limit to national partiality (see Nathanson 2017; Brock 2009, chap. 10). Favoring conationals in a way that requires the violation of the human rights of foreigners clearly exceeds any plausible upper limit of acceptable national partiality. While what counts as a violation as opposed to a non-fulfillment of a human right is a hard matter to resolve, what seems clear is that Donald Trump's attempt to lay claim to all of the available global stock of Remdesivir (in keeping with his America First policy), and wealthy states buying up more doses of the vaccine than they need seems to us to be a case of depriving others from a basic good and not just a case of non-assistance. That is to say, it is a case of depriving or blocking access, not just failing to help or assist.

So the wide scope for partiality that is justified under relational theories presumes reasonably favorable conditions, namely that universal human rights are not threatened in the process, and favoritism for conationals involves special duties that are consistent with the respect for the rights of others. So partiality can justify prioritizing the health needs of compatriots if and only if due consideration is paid to impartial human rights. 
But what about a crisis situation in which what we are confronted with is not a trade-off between the basic right of strangers and some less urgent interests of conationals, but a conflict of equally basic rights? In a global pandemic, where the basic health needs of all are under threat, does that fact of conationality make a moral difference? When all else is equal does the fact of shared nationality provide an additional reason to prioritize one person's claim over another's? Consider this passage from David Miller, no doubt proposed as a thought experiment (in 2007), that unfortunately has become all too real in the time of COVID-19:

Suppose that a flu pandemic breaks out and the government has only sufficient vaccine to inoculate a limited number of vulnerable people against the disease. It does not seem wrong in this case to give priority to treating compatriots, that is to supply the vaccine to all those fellow citizens identified by age or other relevant criteria as belonging to the vulnerable group, before sending any surplus abroad, even though it is reasonable to assume that some foreigners will be more vulnerable to the flu than some compatriots selected for vaccination. And this remains true even if we know that those more vulnerable foreigners will not receive the vaccine from their own health services (Miller 2007, p. 45; emphasis in original).

What can we make of this passage? Miller accepts that if scarcity forces us to favor conationals such that we can't fulfil our positive human rights obligations (e.g. to meet basic needs), we must endeavor to "act on background duties that make it more likely that that right will be fulfilled in time" (ibid., p.195). Hence, our exercise of national partiality has to be accompanied by our taking on other responsibilities to hasten the end of conditions of scarcity if we can. For example, if a country decides to exercise vaccine nationalism (in ways that violate the rights of others), it is obliged then to tackle background conditions that have prevented other countries from getting access to vaccines by means of economic assistance and humanitarian aid, suspending patent rights to permit the productions of generics and so on.

Counter-balancing an exercise of partiality in one sphere of action (e.g., vaccine distribution) by doubling down on impartial duties in another (e.g., economic assistance) is one step towards reconciling necessary partiality with the demands of impartial justice. But, as outlined in the introduction, the relational approach is subject to further constraints.

First, if exercising national partiality during a crisis will exacerbate existing global injustices, the permissibility of partiality becomes questionable. Now, much turns on what we mean by global injustice here. But it seems uncontroversial that minimally, global injustice is offended against when there are people suffering from extreme poverty and are unable to meet even their most basic needs, when the average life expectancy in some countries is below 55 years, or when an economic lockdown in response to a pandemic means making the choice to let people die from starvation rather than the disease. As noted above, the main justifications of partiality, even on the relational approach, affirm some impartial global duty to help ensure a global minimum for all persons. Accordingly, if rich countries engage in vaccine nationalism of the kind that deprives poor countries of the opportunity to reduce premature deaths due to COVID-19 so that they can return their own economies to full functioning as quickly as possible, this would seem to exceed the limits of acceptable national partiality. Indeed, vaccine nationalism is this case amounts to a double injury: people already unjustly deprived - who are suffering from basic health deficits and extreme poverty - are further deprived due to crisis nationalism on the part of the affluent. The fact of extreme global injustice already implies a moral failure on the part of affluent countries. Their exercise of partiality during a crisis compounds an already serious moral failure. 
The requirement that partiality not aggravate existing injustice connects to a second consideration: the ability of a country to acquire the goods with which to favor their own population must not be because of its unjust advantages vis-à-vis other countries. The general idea here is as follows: if I have more resources than others due to background injustice, then I have no morally legitimate title to use these resources as I see fit, either for my own ends or to the benefit of my friends or family. At the very least, the justness of my doing so is questionable. Thus if Canada is able to purchase enough vaccines to vaccinate each citizen five times because it is enjoys unfair economic and political advantages against other countries, this should give us pause over the permissibility of this acquisition. The fact that Canada has purchased more doses per head of population than the USA or the UK may not raise moral problems for us; but affluent countries' ability to acquire vaccines instead of countries like Zimbabwe and Mexico raises moral questions. What facts about the world make it such that Canada is in a very good position to contract with companies to reserve stockpiles for its own population, enable it to support domestic vaccine research and production, and enable it to command global production and distribution of essential goods? Are these facts due to systemic global injustice? If so, partiality here seems unjustifiable.

Defenders of the relational approach will claim that the non-reductive character of special duties means there can be instances in extremis where we have a genuine moral conflict. In a global pandemic, it can be argued that a country can be genuinely forced to choose between meeting the needs of its population versus those of non-members, and an implication of saying that special duties are non-reductive is that there is no simple resolution of such a conflict of values. But even if the relational thesis is right and that there can be genuine moral conflicts, it does not follow that crisis nationalism is straightaway justifiable and exercisable without constraints. An acceptable crisis nationalism must be the outcome of a sincere moral consideration of how to balance the needs of one's own versus the needs of strangers. That is, when we acknowledge the presence of a moral conflict, we must accept an obligation to earnestly acknowledge and address the competing demands and not hastily reject one or the other set of opposing considerations. Thus justifiable partiality in this case must be the result of genuine deliberation about moral responsibility, not its starting point. Countries have duties to their own citizens, including duties of justice and duties to protect their most basic interests. But they also have global duties beyond their borders, including a duty to respect and protect basic human rights, a duty of humanitarian assistance, a duty of economic distribution and the like. Introducing the problem of partiality does not extinguish our global duties. The challenge of partiality, rather, is this: how best to understand the extent of these global duties against the special duties to conationals. This can mean that countries have latitude or some discretionary space as to how to make the trade-off, and we can even disagree with how some have opted to make the trade-off but still accept the partiality as justifiable if the decision is the outcome of genuine tussle with these competing demands. Again, what counts as a genuine confrontation with competing claims is not easy to define. What is clear however is that absolute partiality or partiality at any cost without regard at all for the needs of others - as in Trump's America First doctrine - shows a failure of contemplation.

In short, even nonreductive relational duties must be constrained by impartial moral duties. Even if the very idea of friendship means that friends have relational duties to each other that are not reducible (instrumentally or derivatively) to general impartial principles, it does not mean that friends get to do for each other whatever they want (Brock 2009, chap. 10; Nathanson 2017). Their special concern for each other is going to be limited by what they owe to people at large. The main relational theorists we noted above (e.g., Miller 2007 and Scheffler 2001) all acknowledge impartial 
constraints on partiality. Where the difference is will be in where they draw the line, what counts as these impartial global constraints in the case of national partiality. But all will agree at minimum that violations of basic human rights constitute a violation of impartial constraints, and our claim here is that the burden of proof will be on defenders of partiality to show that favoring conationals during a global crisis does not breach these minimum constraints.

Protecting a basic right or interest of a conational over a non-member may be more compelling to us simply in virtue of the relationship we share; but whether this means that partiality is therefore morally uncompromised cannot be resolved without addressing the background conditions in which partiality is to be exercised. If protecting a basic right of a fellow member means that I accentuate an existing injustice, or if I can do so only because I enjoy unfair advantages, or if I do this without regard whatsoever for the rights of others, then the exercise of partiality is morally impaired.

\section{The Limits of Crisis Nationalism}

The COVID-19 pandemic presents a challenge for global justice: how should affluent countries balance their special duties to their own citizens and residents against their impartial duties of global justice? Is partiality during a crisis - what we have called crisis nationalism more permissive since the basic rights or interests of compatriots are at stake?

We examined three approaches to national partiality to see how they might defend crisis nationalism. Although these arguments are not uncontroversial as justifications of national partiality, we highlighted a more general point, to wit that even if these arguments succeed in defending national partiality, they presume various moral limits to national partiality (e.g., Nathanson 2017; Brock 2009; Tan 2003). To recall, the instrumental approach justifies and thereby limits partiality by appeal to what is globally felicitous; the institutional approach gets off the ground by presuming certain universal principles and duties (e.g., a universal principle of autonomy or a general duty of reciprocity) that serve as built-in constraints on partiality; and the relational approach justifies partiality on the condition that background justice obtains or is not fully neglected in the exercising of partial concern.

The first two approaches presume the truth of certain impartial moral goals or principles; the third (the relational approach) understands morality to be a complex interplay between partial and impartial duties and that certain impartial duties provide the bounds of permissible partiality. In other words, the prerogative or even duty to serve the basic needs or interests of compatriots does not give governments free rein to neglect all responsibilities beyond their own borders. Global responsibilities are not extinguished simply because nations find themselves in a crisis.

Our argumentative strategy is ecumenical: regardless of the kind of argument one might forward in defense of national partiality, one has to accept moral limits to crisis nationalism. We grant that on some approaches to partiality, there can be a genuine moral conflict between special concern for compatriots and impartial global duties in times of crisis. But even here, as we noted above, morally acceptable partiality, even in times of crisis, requires a sincere adjudication of the competing partial and impartial responsibilities. This proposal inevitably grants countries some latitude in how they choose to balance their competing global and national duties. But analogously with Kantian imperfect duties, it can be clear when a country is disregarding its global responsibilities altogether, when an exercise of partiality is taken as a starting point rather than an outcome of moral deliberation, and thereby is not exercising 
partiality in good faith. For instance, extreme vaccine nationalism of the kind that prompts governments to stockpile vaccines for its own population without any due consideration of the impact of this on other countries seems to be a case of bad faith partiality. Suppose we take the principle of fair global distribution of COVID-19 vaccines to be that of minimizing premature deaths due to the pandemic (Emanuel et al. 2020). ${ }^{11}$ If so, then a case of vaccine nationalism that seeks to hoard vaccines in order to return a country to full normalcy, while premature deaths due to COVID-19 persist elsewhere, seems to be a case of partiality that has entirely ignored the requirements of impartial morality.

We can say that good faith national partiality is partiality that is counterbalanced by impartial actions. This is because the best evidence that a case of national partiality is not one that is completely dismissive of impartial duties is when a country does its part to promote global justice even as it is compelled to be partial in some respects. So if a country wishes to stockpile vaccines for its own members, it should for example, provide other countries with the means to acquire enough and as good for themselves, to liberate them from restrictive international patent laws, or to provide economic assistance to countries whose economies are being devastated by lockdowns that they are compelled to impose because of their lack of access to a vaccine. That is, good faith partiality is a partiality that recognizes the potential moral costs of partiality, and is thus accompanied by actions to mitigate or assuage these costs. We might call this a paradox of partiality: even in a genuine crisis, national partiality is permissible only when a country takes its basic responsibility of global justice seriously.

Acknowledgments We would like to thank the members of the Penn Normative Philosophy Group for their feedback and questions, Justin Bernstein for his extensive written comments, and the two reviewers and the editors of this journal for their very constructive criticisms and suggestions.

\section{References}

Abizadeh A (2007) Cooperation, pervasive impact, and coercion: on the scope (not site) of distributive justice. Phil \& Pub Affairs 35(4):318-358

Abizadeh A (2008) Democratic theory and border coercion: no right to unilaterally control your own borders. Pol Theory 36 (1):37-65. https://doi.org/10.1177/0090591707310090

Al Jazeera (2020) WHO lists Pfizer-BioNTech COVID vaccine for emergency use. https://www.aljazeera.com/ news/2020/12/31/who-lists-pfizer-biontech-covid-vaccine-for-emergency-use

Arneson RJ (2016) Extreme cosmopolitanisms defended. CRISPP 19(5):555-573. https://doi.org/10.1080/ 13698230.2016 .1183751

Banai A, Kollar E (2019) Reading bedtime stories to compatriots: reconciling global equality if opportunity and self-determination. Rev Int Stud 45(3):367-386

Barry C, Valentini L (2009) Egalitarian challenges to global egalitarianism: CRISPP 35(3): 485-512

Bieber F (2020) Global nationalism in times of the COVID-19 pandemic. Nationalities Papers https://www. cambridge.org/core/journals/nationalities-papers/article/global-nationalism-in-times-of-the-covid19pandemic/3A7F44AFDD6AC117AE05160F95738ED4, 1, 13

Blake M (2001) Distributive justice, state coercion, and autonomy. Phil \& Pub Affairs 30(3):257-296

Bollyky TJ and Bown CP (2020) The tragedy of vaccine nationalism . Foreign Affairs. https://fam.ag/32sqwZ7

\footnotetext{
${ }^{11}$ Compare with World Health Organization (2020). Premature deaths is based on standard expected years of life lost (SEYLL) rather than actual life expectancies in countries. SEYLL determines "life years lost" based on a normalized life expectancy table, e.g., 72 years as the standard for all countries. Thus SEYLL does not disadvantage countries with low life expectancy.
} 
Boseley, S. (2020) Nine out of 10 people in poor nations to miss out on inoculation as west buys up Covid vaccines. The Guardian. Available from: https:/www.theguardian.com/society/2020/dec/09/nine-out-of-10in-poor-nations-to-miss-out-on-inoculation-as-west-buys-up-covid-vaccines

Brock G (2009) Global justice: a cosmopolitan account. Oxford University Press, Oxford

Carens J (1987) Aliens and citizens: the case for open borders. Rev Pol 49(2):251-273. https://doi.org/10.1017/ S0034670500033817

Emanuel E, Persad G, Kern A et al (2020) An ethical framework for global vaccine allocation. Science 369: 1309-1312. https://doi.org/10.1126/science.abe2803

Freeman S (2007a) Rawls. Routledge, New York

Freeman S (2007b) Justice and the social contract. Oxford University Press, New York

Goodin RE (1988) What is so special about our fellow countrymen? Ethics 98(4):663-686. https://doi.org/10. $1086 / 292998$

Hurka T (1997) The justification of national partiality. In: McKim R and McMahan J (eds) The morality of nationalism. Oxford University Press, Oxford

Lazar S (2010) A Liberal Defence of (some) duties to compatriots. J Appl Philos 27(3):246-257. https://doi.org/ $10.1111 /$ j.1468-5930.2010.00496.x

Lazar S (2016) The justification of associative duties. J Moral Philos 13:28-55. https://doi.org/10.1163/ $17455243-4681050$

McMahan J (1997) The limits of national partiality. In: McKim R and McMahan J (eds) The morality of nationalism. Oxford University Press, Oxford

Miller D (1995) On nationality. Oxford Political Theory. Oxford University Press, Oxford

Miller D (2007) National Responsibility and global justice. Oxford University Press, Oxford

Miller R (1998) Cosmopolitan respect and patriotic concern. Phil \& Pub Affairs 27(3):202-221

Moore M (2001) The ethics of nationalism. Oxford University Press

Moore M (2015) A political theory of territory. Oxford Political Philosophy. Oxford University Press, New York

Nagel T (2005) The problem of global justice. Phil \& Pub Affairs 33(2):133-147

Nathanson S (2017) Moderate patriotism. In: Springer handbook of patriotism. https://ink.springer.com/ referenceworkentry/10.1007/978-3-319-30534-9 26-1

Nussbaum M (1996) Patriotism and cosmopolitanism. In: Cohen JC (ed) For love of country: debating the limits of patriotism. Beacon Press, Boston, pp 2-17

Rawls J (1999) A theory of justice, revised edn. Belknap Press of Harvard University Press, Cambridge

Sangiovanni A (2007) Global justice, reciprocity, and the state. Phil \& Pub Affairs 35(1):3-39

Scheffler S (1994) Families, nations, and strangers. The Lindley Lecture at the University of Kansas

Scheffler S (2001) Boundaries and allegiances: problems of justice and responsibility in liberal thought. Oxford University Press, Oxford

Scheffler S (2018) Membership and political obligation. J Polit Philos 26(1):3-23. https://doi.org/10.1111/jopp. 12125

Tan K-C (2003) Patriotic obligations. Monist 86(3):434-453. https://doi.org/10.5840/monist200386319

United Nations Secretary-General (2020) Secretary-General's message to the Nobel Peace Prize Forum. Available from: https://www.un.org/sg/en/content/sg/statement/2020-12-11/secretary-generals-videomessage-the-nobel-peace-prize-forum

Valentini L (2011) Coercion and (global) justice. Amer Pol Sci Rev 105(1):205-220

Viroli M (1995) For love of country: an essay on patriotism and nationalism. Oxford University Press, New York

Wellman C H (2001) Friends, compatriots, and special political obligations. Pol Theory 29 (2):217-236. https:// doi.org/10.1177/0090591701029002003

West-Oram PGN, Buyx A (2017) Global health solidarity. Public Health Ethics 10(2):212-224

World Health Organization (2020) Press Release. https://www.who.int/news-room/detail/15-07-2020-more-than150-countries-engaged-in-covid-19-vaccine-global-access-facility

Yamey G, Schäferhoff M, Hatchett R, Pate M, Zhao F, McDade KK (2020) Ensuring global access to COVID19 vaccines. Lancet 395(10243):1405-1406. https://doi.org/10.1016/S0140-6736(20)30763-7

Young, Iris Marion (2011) Responsibility for justice. Oxford University Press

Publisher's Note Springer Nature remains neutral with regard to jurisdictional claims in published maps and institutional affiliations. 


\section{Affiliations}

Eilidh Beaton ${ }^{1} \cdot$ Mike Gadomski $^{2} \cdot$ Dylan Manson $^{2} \cdot$ Kok-Chor Tan ${ }^{2}$

1 Department of Political Economy, King's College London, London, UK

2 Department of Philosophy, University of Pennsylvania, Philadelphia, PA, USA 